\title{
A Study on Regional Environmental Hygiene in View of Complaints about Public Nuisances in Rural District
}

\author{
Yoshiharu HORI*, Tamotsu MIYOSHI*, Masahide IMAKI* \\ and Takeshi YOSHIMURA*
}

\begin{abstract}
Summary
This survey was conducted in a local city, Tokushima for its 23 administrative sections, which were classified into rural, non-rural and mixed districts based on the data related to agriculture. Complaints of public nuisances in these districts have been examined and the following findings have been obtained.

1. Complaints about water pollution and offensive odor in the rural district and those about offensive odor and noise in the mixed district have been raised more often, respectively. While, in the non-rural district more complaints about noise have been raised. Thus, it is recognized that possible pollution phenomena vary depending on regional patterns.

2. In time-serial comparison between the first half (1977-1980) and the second half (1981-1984) of survey period, it is found that total complaints of public nuisances have been reduced and the complaints in the rural district have been increased for all the types excepting dust. Therefore, it is suggested that regional environment in suburban farm villages has been deteriorating.
\end{abstract}

(1) regional environmental hygiene (2) complaints of public nuisances (3) rural district (4) environmental pollution (5) offensive odor

\section{INTRODUCTION}

During the period of rapid economic growth, serious environmental pollution had occurred in many areas throughout Japan, causing the country to be confronted with a significant crisis of environmental disruption ${ }^{1)}$. After that, however, what is called industrial pollution has begun to show a sign of subsiding due to the strong opposition coming from society requiring more and better pollution control and as a result of stagnation of economic activities resulting from the oil crisis.

On the other hand, traffic pollution ${ }^{2}$, community noise ${ }^{3)}$ and other urban-life-related pollution still are prevalent in today's environment, constituting the mainstream of today's environmental problems. Moreover, this tendency seems to have estended to local cities, not to speak of big cities, due to the prevalence of the urbanized life-style and under the influence of the information-oriented society. Nowadays, in local cities scattering urbanization and mixing of farming and non-farming households in peripheral areas have been progressing, and it has been reported that environmental problems are continuing unabated threatening our future environment and life-style ${ }^{4)}$.

In the previous report ${ }^{5)}$, the authors examined the relationship between social environmental factors and complaints of public nuisances as a regional environmental indices. As a result, it was recognized that complaints of public nuisances can be a useful index for the promotion of regional environmental hygiene. This time the authors have observed first hand public nuisance complaints in rural, non-rural and mixed districts in a local city and examined the difference in regional environ-

\footnotetext{
* Department of Public Health, School of Medicine, The University of Tokushima
} 
mental hygiene among these districts. As a result, the authors have obtained a good deal of beneficial knowledge, which will be reported in the following.

\section{AREA SURVEYED AND METHODS USED}

1. Outline of the Area

The area surveyed is Tokushima City, where land use is as follows: urbanized area is 3,708 ha. (19.7\%), urbanization-controlled area is 15,106 ha. (80.3\%), the total being 18,800 ha. In the urbanized area, urbanized land use for residential houses, commerce, industry and other purposes takes up $70.2 \%$ of the total land area, while natural land use for farmland, forest land and other related uses makes up the remaining $29.8 \%$. In the urbanizationcontrolled area, on the other hand, the share of urbanized land use is $12.5 \%$, while that of natural land use amounts to $87.5 \%$, in which land use for farmland and for forest land is $36.3 \%$ each.

\section{Data}

Analyses were conducted on the basis of the following data obtained from 23 administrative sections forming Tokushima City.

\section{1) Complaints of Public Nuisances}

Complaints of public nuisances of 1,278 cases were used which have been accepted by Tokushima City from its citizens over an 8 year period from 1977 to 1984 and classified into 6 types of air pollution (dust - soot and smoke), water pollution, noise, vibration and offensive odor.

\section{2) Data of Regional Patterns}

The results of the "1980 Population Census of Japan" conducted in October, 1980 were used for the population, number of households and rate of persons 15 years old and over employed in agriculture in each administrative districts, and other data related to agriculture such as the farming households population, the rate of the farming household population and number and rate of farming households were cited from the " 1980 World Agriculture and Forestry Census".

\section{RESULTS}

\section{Progress of Complaints of Public Nuisances}

Figure 1 shows the progress of complaints of public nuisances. The number of complaints peaked in 1977 at 224 and thereafter showed a tendency and to decrease in general although there were some fluctuations up and down, until now. Classified by type of complaint, noise was at the top of the list with a level as show high as $30-40 \%$ of the total. Complaints of air pollution (dust $\cdot$ soot and smoke) and of offensive odor follow those of noise, their rankings showing some change in position each year. On the other hand, the ratio of complaints directed against water pollution and of vibration as

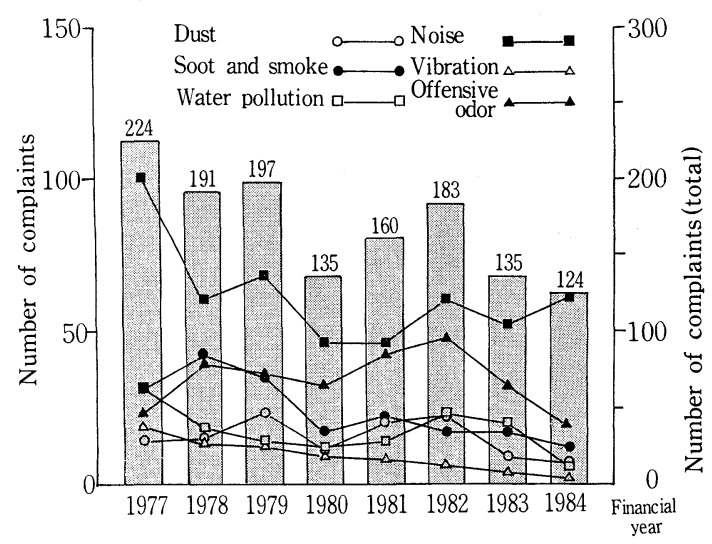

Fig. 1 The progress of complaints of public nuisances.

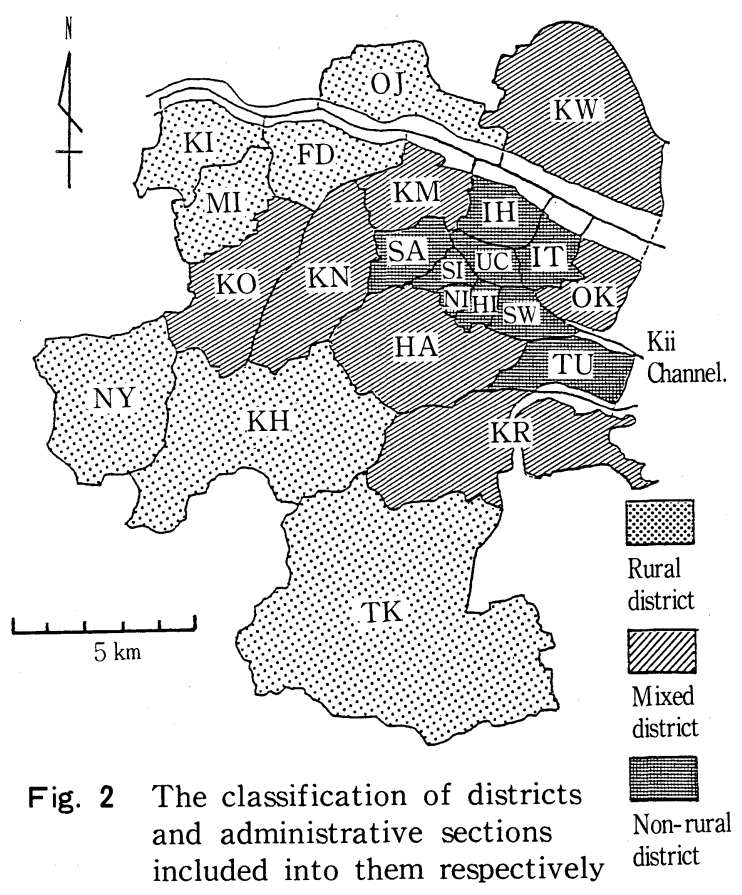


Table 1 The classification of districts by using the data related to agriculture.

\begin{tabular}{|c|c|c|c|c|c|c|c|c|c|}
\hline \multicolumn{2}{|c|}{$\begin{array}{l}\text { Administrative } \\
\text { section }\end{array}$} & $\begin{array}{c}\quad \text { Area } \\
\left(\begin{array}{l}\text { square } \\
\text { kilometers }\end{array}\right)\end{array}$ & Population & Households & $\begin{array}{l}\text { Farming } \\
\text { population }\end{array}$ & $\begin{array}{c}\text { Rate of } \\
\text { farming } \\
\text { population } \\
(\%)\end{array}$ & $\begin{array}{l}\text { Farming } \\
\text { households }\end{array}$ & $\begin{array}{c}\begin{array}{c}\text { Rate of } \\
\text { farming } \\
\text { households } \\
(\%)\end{array} \\
\end{array}$ & $\begin{array}{l}\text { Rate of }{ }^{*} \\
\text { engaged in } \\
\text { agriculture } \\
(\%)\end{array}$ \\
\hline \multirow{4}{*}{ Rural } & $\mathrm{OJ}$ & 9.06 & 6,676 & 1,791 & 2,462 & 36.9 & 536 & 29.9 & 16.8 \\
\hline & $\mathrm{F} \quad \mathrm{D}$ & 7.33 & 3,687 & 1,069 & 1,297 & 35.2 & 280 & 26.2 & 30.1 \\
\hline & K I & 5.76 & 3,495 & 835 & 2,095 & 59.9 & 455 & 54.5 & 44.1 \\
\hline & M I & 4.93 & 4,888 & 1,231 & 2,126 & 43.5 & 443 & 36.0 & 26.4 \\
\hline \multirow{4}{*}{ district } & N Y & 10.85 & 2,660 & 487 & 1,552 & 58.3 & 323 & 66.3 & 31.2 \\
\hline & $\mathrm{K} \mathrm{H}$ & 20.03 & 6,915 & 1,691 & 2,882 & 41.7 & 618 & 36.5 & 20.2 \\
\hline & $\mathrm{T} \mathrm{K}$ & 38.80 & 5,800 & 1,371 & 3,598 & 62.0 & 767 & 55.9 & 43.9 \\
\hline & Total & 96.76 & 34,121 & 8,475 & 16,012 & 46.9 & 3,422 & 40.4 & 30.4 \\
\hline \multirow{8}{*}{$\begin{array}{l}\text { Mixed } \\
\text { district }\end{array}$} & $\mathrm{K} \mathrm{W}$ & 19.21 & 12,468 & 3,850 & 2,678 & 21.5 & 565 & 14.7 & 13.9 \\
\hline & $\mathrm{K} \mathrm{M}$ & 5.63 & 17,009 & 5,555 & & & & & 2.67 \\
\hline & K N & 10.56 & 22,486 & 7,488 & & & & & 3.76 \\
\hline & $\mathrm{K} \mathrm{O}$ & 8.58 & 11,256 & 3,068 & 2,460 & 21.9 & 515 & 16.8 & 13.0 \\
\hline & $\mathrm{H} \mathrm{A}$ & 11.53 & 23,660 & 7,765 & & & & & 3.98 \\
\hline & K R & 15.36 & 10,745 & 3,042 & 2,490 & 23.2 & 541 & 17.8 & 14.8 \\
\hline & $0 \mathrm{~K}$ & 4.26 & 12,391 & 3,887 & & & & & 3.31 \\
\hline & Total & 75.13 & 110,015 & 34,655 & & & & & 7.92 \\
\hline \multirow{5}{*}{ Non-rural } & $\mathrm{UC}$ & 1.53 & 7,640 & 2,598 & & & & & 0.08 \\
\hline & S I & 0.88 & 3,506 & 1,061 & & & & & 0 \\
\hline & N I & 0.61 & 3,596 & 1,390 & & & & & 0.27 \\
\hline & $\mathrm{H} \mathrm{I}$ & 0.74 & 9,499 & 3,499 & & & & & 0.15 \\
\hline & $\mathrm{SA}$ & 1.80 & 15,675 & 5,533 & & & & & 0.49 \\
\hline \multirow{5}{*}{ district } & S W & 1.84 & 12,193 & 4,638 & & & & & 0.09 \\
\hline & I H & 2.60 & 18,915 & 7,173 & & & & & 0.78 \\
\hline & $\mathrm{I} \mathrm{T}$ & 2.92 & 17,289 & 6,047 & & & & & 0.57 \\
\hline & $\mathrm{T} \mathrm{U}$ & 3.34 & 16,894 & 5,042 & & & & & 0.38 \\
\hline & Total & 16.26 & 105,207 & 36,981 & & & & & 0.31 \\
\hline \multicolumn{2}{|c|}{ All city } & 188.15 & 249,343 & 80,111 & 29,371 & 11.8 & 6,270 & 7.8 & 7.22 \\
\hline
\end{tabular}

regards the total shows a decreasing tendency.

2. Classification of Districts in View of Agriculture

By using the data related to agriculture classification districts is made and shown in Table 1. Seven administrative sections, which have each $30 \%$ or more in the rate of the farming household population, $20 \%$ or more in the farming household rate and $15 \%$ or more in the rate of persons of 15 years old and over employed in agriculture, are classified into "rural district". Nine sections, where the rate of persons of 15 years and over employed in agriculture is $1 \%$ or less each, are classified into "non-rural district" and other 7 sections into "mixed district". The classification of districts and administrative sections included into them respectively are shown in Fig. 2.

3. Complaints of Public Nuisances by the Districts Table 2 shows the accumulated number of complaints about public nuisance in each district for the 8 year period from 1977 to 1984 . The total complaints number 630 in the mixed district, 553 in the non-rural district and 166 in the rural district in that order. According to type of complaints, complaints of noise in the non-rural and the mixed districts are dominant, followed by complaints of 
Table 2. The accumulated number of complaints about public nuisances in each district for the 8 year period from 1977 to 1984 .

\begin{tabular}{|c|c|c|c|c|c|c|c|c|c|}
\hline \multicolumn{2}{|c|}{$\begin{array}{l}\text { Administrative } \\
\text { section }\end{array}$} & \begin{tabular}{|l|} 
All \\
complaints \\
\end{tabular} & Dust & $\begin{array}{l}\text { Soot and } \\
\text { smoke }\end{array}$ & $\begin{array}{l}\text { Water } \\
\text { pollution }\end{array}$ & Noise & Vibration & $\begin{array}{l}\text { Offensive } \\
\text { odor }\end{array}$ & others \\
\hline \multirow{8}{*}{$\begin{array}{l}\text { Rural } \\
\text { district }\end{array}$} & $\mathrm{O} \mathrm{J}$ & 57 & 5 & 8 & 9 & 18 & 3 & 9 & 5 \\
\hline & $\mathrm{F} \quad \mathrm{D}$ & 49 & 2 & 8 & 6 & 8 & 1 & 18 & 6 \\
\hline & $\mathrm{K} \quad \mathrm{I}$ & 12 & 0 & 0 & 3 & 3 & 0 & 2 & 4 \\
\hline & M I & 20 & 1 & 0 & 5 & 5 & 0 & 4 & 5 \\
\hline & $\mathrm{N} \quad \mathrm{Y}$ & 6 & 0 & 0 & 2 & 1 & 0 & 1 & 2 \\
\hline & $\begin{array}{ll}\mathrm{K} & \mathrm{H}\end{array}$ & 6 & 0 & 0 & 1 & 2 & 0 & 2 & 1 \\
\hline & $\mathrm{T} \mathrm{K}$ & 16 & 3 & 0 & 5 & 2 & 0 & 6 & 0 \\
\hline & Total & 166 & 11 & 16 & 31 & 39 & 4 & 42 & 23 \\
\hline \multirow{8}{*}{$\begin{array}{l}\text { Mixed } \\
\text { district }\end{array}$} & $\mathrm{K} \quad \mathrm{W}$ & 83 & 6 & 15 & 8 & 25 & 2 & 24 & 3 \\
\hline & $\mathrm{K} \mathrm{M}$ & 138 & 12 & 20 & 12 & 43 & 10 & 34 & 7 \\
\hline & $\mathrm{K} \mathrm{N}$ & 109 & 6 & 17 & 11 & 37 & 8 & 25 & 5 \\
\hline & $\mathrm{K} \mathrm{O}$ & 73 & 5 & 3 & 20 & 25 & 3 & 12 & 5 \\
\hline & $\mathrm{H} \quad \mathrm{A}$ & 77 & 0 & 15 & 12 & 27 & 3 & 18 & 2 \\
\hline & $\mathrm{K} \quad \mathrm{R}$ & 44 & 1 & 3 & 11 & 19 & 1 & 7 & 2 \\
\hline & $\mathrm{O} \mathrm{K}$ & 106 & 16 & 19 & 3 & 36 & 6 & 23 & 3 \\
\hline & Total & 630 & 46 & 92 & 77 & 212 & 33 & 143 & 27 \\
\hline \multirow{11}{*}{$\begin{array}{l}\text { Non- rural } \\
\text { district }\end{array}$} & $\mathrm{UC}$ & 58 & 2 & 8 & 1 & 32 & 4 & 7 & 4 \\
\hline & S I & 26 & 0 & 6 & 1 & 12 & 3 & 4 & 0 \\
\hline & $\mathrm{N} \quad \mathrm{I}$ & 13 & 1 & 1 & 0 & 6 & 2 & 2 & 1 \\
\hline & $\mathrm{H} \quad \mathrm{I}$ & 46 & 2 & 4 & 1 & 23 & 6 & 9 & 1 \\
\hline & S A & 54 & 5 & 7 & 0 & 25 & 5 & 8 & 4 \\
\hline & S W & 79 & 9 & 11 & 1 & 39 & 3 & 16 & 0 \\
\hline & I $\mathrm{H}$ & 61 & 5 & 7 & 7 & 26 & 5 & 9 & 2 \\
\hline & I $\mathrm{T}$ & 139 & 31 & 27 & 6 & 57 & 3 & 12 & 3 \\
\hline & $\mathrm{T} \quad \mathrm{U}$ & 77 & 8 & 14 & 3 & 22 & 5 & 19 & 6 \\
\hline & Total & 553 & 63 & 85 & 20 & 242 & 36 & 86 & 21 \\
\hline & 1 city & 1349 & 120 & 193 & 128 & 493 & 73 & 271 & 71 \\
\hline
\end{tabular}

offensive odor in the mixed district. Table 3 shows the accumulated number of complaints per 10 thousand inhabitants. The non-rural district has the greatest number of complaints regarding dust, noise and vibration, followed by the mixed and the rural district in that order. The number of these complaints coming from the non-rural district amounts to approximately twice as many as those in the rural district. The mixed district has the greatest number of complaints of soot and smoke and offensive odor, the non-rural and the rural districts follows it in that order regarding complaints of soot and smoke, and the rural and the non-rural districts follows in that order for complaints of offensive odor. On the other hand, complaints of water pollu-
Table 3. The accumulated number of complaints per 10 thousand inhabitants in each district.

\begin{tabular}{|c|c|c|c|c|}
\hline complaint & $\begin{array}{l}\text { Rural } \\
\text { district }\end{array}$ & $\begin{array}{l}\text { Mixed } \\
\text { district }\end{array}$ & $\begin{array}{l}\begin{array}{l}\text { Non- rural } \\
\text { district }\end{array} \\
\end{array}$ & All city \\
\hline Dust & 3.2 & 4.2 & 6.0 & 4.8 \\
\hline Soot and smoke & 4.7 & 8.4 & 8.1 & 7.7 \\
\hline Water pollution & 9.1 & 7.0 & 1.9 & 5.1 \\
\hline Noise & 11.4 & 19.3 & 23.0 & 19.8 \\
\hline Vibration & 1.2 & 3.0 & 3.4 & 2.9 \\
\hline Offensive odor & 12.3 & 13.0 & 8.2 & 10.9 \\
\hline All complaints & 48.7 & 57.3 & 52.6 & 54.1 \\
\hline
\end{tabular}




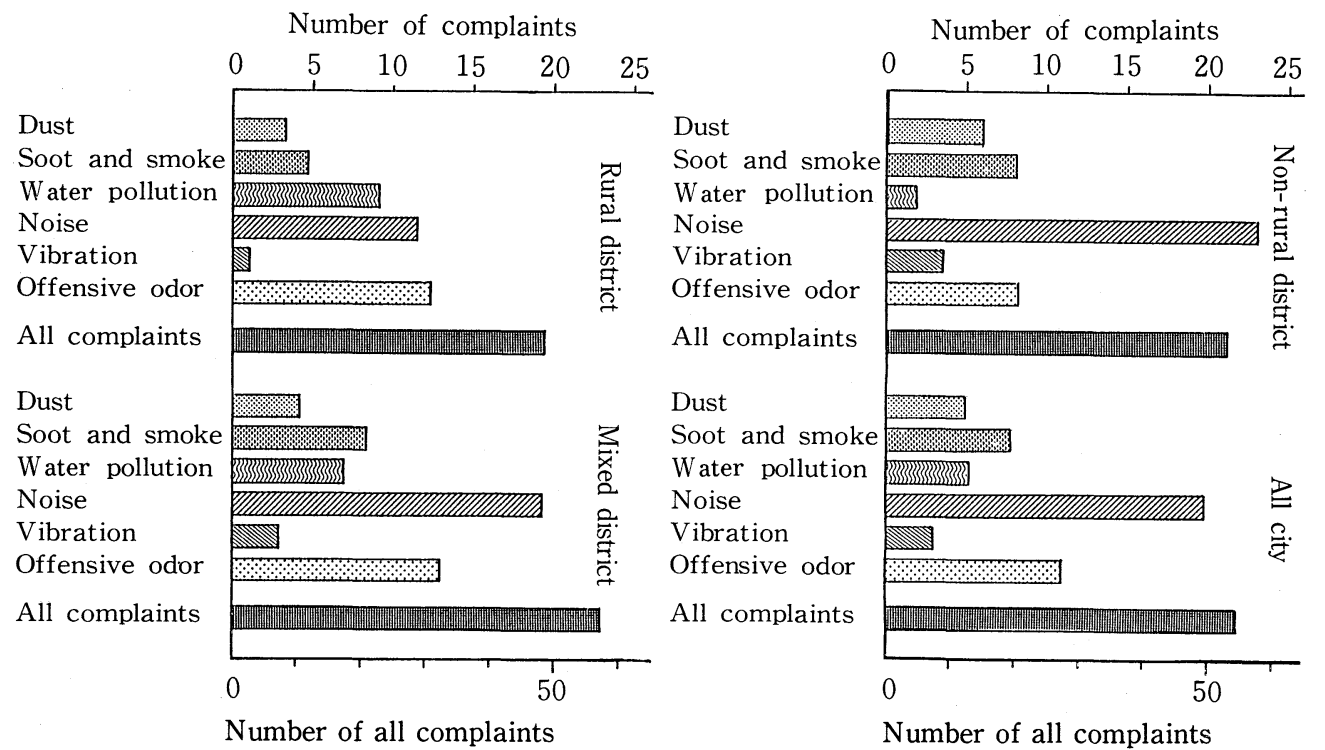

Fig. 3 The accumulated number of complaints of public nuisances per 10 thousand inhabitants by districts.

tion come mostly from the rural district, followed by the mixed and the non-rural districts in that order, and the number of complaints coming from the rural district is about 5 times as many as that in the non-rural district.

Figure 3 shows the accumulated number of complaints per 10 thousand inhabitants by districts. In the rural district complaints of offensive odor are the highest in number, followed by the number of complaints of noise, water pollution, soot and smoke, dust and vibration in that ordor. The mixed district has the most complaints regarding noise, followed by those of offensive odor, soot and smoke, water pollution, dust and vibration in that order. In the non-rural district also complaints of noise has the greatest number, followed by the number of complaints of offensive odor, soot and smoke, dust, vibration and water pollution in that order.

4. Progress of the Accumulated Numbers of Complaints about Public Nuisances by the Districts

Figure 4 shows the progress of the accumulated number of complaints about public nuisances from the first half to the second half of the survey period in each district. Generally speaking, the number of complaints have been reduced in the mixed and non-rural district, while they have tended to increase in the rural district. Especially, complaints of offensive odor and noise have increased in the rural district, while complaints about vibration, water pollution and soot and smoke in the mixed district and those about vibration, soot and smoke and dust in the non-rural district have been on the decrease. Figure 5 shows the progress of the occurrence rate of complaints about public nuisances by the events in each district. The share of the rural district tends to increase for the all districts except dust.

\section{DISCUSSION}

Itai-itai disease, Minamata disease and other serious pollution-related diseases occurred in the past in Japan ${ }^{6}$. Itai-itai disease and Minamata disease are both industrial pollution generated on the basis of the farm-village-type community and the fishing-village-type community, respectively. It is known that either of these diseases is deeply related to the primary industry, and many studies on them have been made in preventive medicine and treatment $^{7 \sim 9)}$. Many reports on the pollution by agricultural chemicals have also been made as one of the environmental problems in the rural district $^{10 \sim 12)}$. However, few complaints of this pol- 


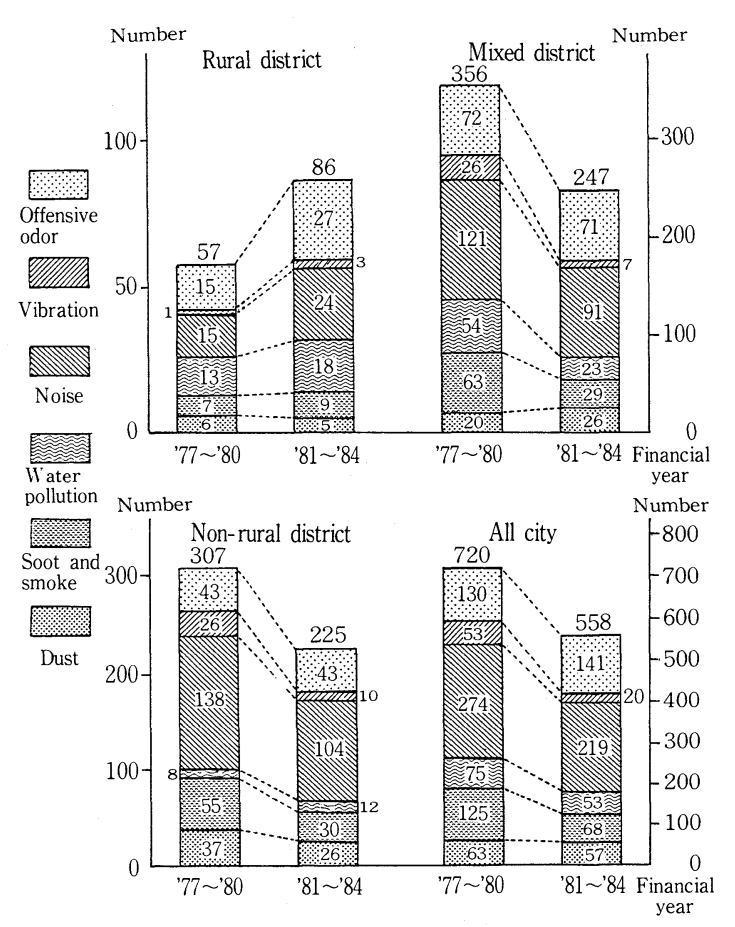

Fig. 4 The progress of the accumulated number of complaints about public nuisances from the first half to the second half of the survey period in each district.

lution as an appearance of regional environmental problems have been reported, and especially almost none for the rural district ${ }^{13,14)}$.

The authors examined last time the relationship between complaints of public nuisances and socio-environmental factors such as urban infrastructure and recognized that the former can be socio-hygienically a useful index of regional environmental hygiene. Therefore, it is considered to be important for environmental hygiene in rural district to examine complaints about public nuisances ther $\mathrm{e}^{15,16)}$. This time, the authors have examined, from a practical viewpoint, environmental hygiene in farm villages by observing the actual conditions of complaints about public nuisances and regional environment. In this survey, three districts which show different regional patterns have been examined and the progress from the first half to the second half of the survey period has been investigat-
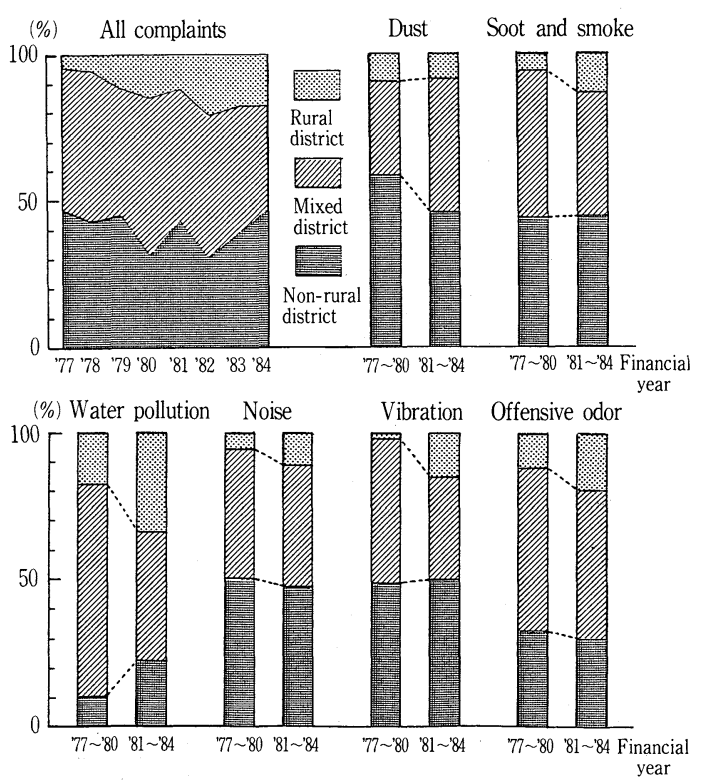

Fig. 5 The progress of the occurrence rate of complaints about public nuisances by the events in each district.

ed. The non-rural district in this survey does not directly mean an urban area, but an area mixing residential and industrial districts and including fishing villages.

At first, when complaints of public nuisances are examined by the events, those of dust, noise and vibration are found most often in the non-rural district, next in the mixed district and in the rural district in order. This would be because that the non-rural district has within it a section concentrating factories related to the woodworking industry which is a local industry in Tokushima City. Many of the complaints of noise and vibration are considered to be raised in relation to civil engineering and constructing works in the urban district. However, the difference between the non-rural and the mixed districts is not so remarkable, which seems to show the progress of diffusion of factories into the mixed district. Complaints of soot and smoke are seen more often in the mixed and non-rural districts than in the rural district. This would be because complaints about incinerators of factories in the mixed district and complaints about boilers of business under-takings in the urban district are raised vary 
frequently. On the other hand, complaints of offensive odor are seen more often in the mixed and rural districts than in the non-rural district. This seems due to the fact that complaints related to the livestock industry and farming work are raised very frequently in the mixed and rural districts. Moreover, this would be because that the rural district has within it a section where dead animal processing plants for processing animal bones are located and many complaints of offensive odor are raised in this section and neighbouring mixed district. Complaints about water pollution are seen very often in the rural and mixed districts, and the complaints in the rural district are about 5 times as many as those in the non-rural district. This seems due to the fact that complaints about the pollution of agricultural irrigation canals for water supply purpose with livestock effluent in the rural district and complaints about failure of septic tanks in the mixed district where public sewerage is not provided are raised quite often. Generally speaking, complaints in the mixed district have tended to increase. It can be considered that this tendency is partly due to the mixed habitation of traditional farming households and non-farming households having immigrated from other districts.

As previously discussed, since the rural district has many complaints of offensive odor and water pollution, it is necessary for this district to make up for the delay in antipollution measures of livestockrelated industries in view of environmental hygiene. As complaints about offensive odor, soot and smoke, water pollution and noise are raised very often in the mixed district, it seems that the mixing with farm village due to the progress of disordered urbanization and diffusion of industries is the problem for this district. In order to solve this problem completely, proper urban planning and industrial development are considered to be necessary as has been pointed out since the past ${ }^{17}$. Finally, complaints of noise, vibration and dust have been increasing in the non-rural district. This fact corresponds well to the report ${ }^{18)}$ of the Environmental Disputes Coodination Commission suggesting that the share of complaints about noise, air pollution and vibration in an area becomes higher as popula- tion there increases and this sort of pollution can be considered to be urban-type pollution. From this report, we may infer that the characteristics of urban-type pollution have appeared also in the non-rural district investigated in this survey. These findings, however, are only of a local city, and therefore, investigations in other cities would be necessary in the future.

Next, the results of the time-serial examination conducted for a many-sided observation of actual conditions in these districts are summarised as follows. In view of the variation of complaints about public nuisances from year to year, total complaints have tended to decrease since 1977, having been reduced for the total city area from 720 in the first half of the survey period (1977-1980) to 558 in the second half (1981-1984), which means a decrease of $22.5 \%$. According to the various districts, the mixed district and the non-rural district showed decreases of 30.6 and $26.7 \%$, respectively; while the rural district showed an increases of $50.9 \%$. In accordance to the type of the complaints, complaints about vibration, water pollution, soot and smoke and noise have decreased in the mixed district, while those about vibration, soot and smoke, dust and noise have been reduced in the non-rural district. As for vibration, this tendency seems to be caused by fact that the regulation of vibration has been started by the Vibration Regulation Law in 1978 and vibrationproof techniques in construction work have been developed. On the other hand, for complaints about air pollution and noise efforts by manufacturing under takings for pollution control seem to have brought about a reduction in complaints. We can infer that the reduction of complaints about water pollution in the mixed district has been caused by the expansion of public sewerage and improvements of sewage channels for roads. However, on the contrary to the above-mentioned districts, complaints of all events excluding dust have been increasing in the rural district. Especially, complaints about offensive odor, noise and vibration that are called psycho-sensory public nuisances have been on the increase. Complaints regarding soot and smoke and water pollution have also been raised more often than in other districts. From these 
facts, we can infer that regional environment in the suburban rural area investigated this time has been deteriorating on the whole. Moreover, it seems that consciousness of environment of the inhabitants in the rural district have been changed due to the increase in the psycho-sensory public nuisances. This may be caused by the fact that consciousness of environment increasingly varies between farming households specialized in agriculture and part-time farmers which have been changing to non-farming housesolds ${ }^{19)}$. This may also be caused by sprawling development activities of big collective housing areas which bring about massive immigration of non-farming households into a rural district. Therefore, it may be necessary in the future to carried out studies on consciousness of environment in rural district by means of a social survey.

(The summary of this paper was made public in the 45th General Meeting of Japanese Society of Public Health.)

\section{REFERENCES}

1) Syouji, H. and Miyamoto, K.: Nippon no Kogai, Iwanami-Syoten, Tokyo, Sept. 1975, 31-66.

2) Kaneyasu, K. and Kanaizumi, A.: Kotsu-Kogai, Gizyutsu-Syoin, Tokyo, 1980.

3) Aoki, T. : The Present Condition on Printing Co, Tokyo, 1973.

4) Planning and Coordination Bureau, Environment Agency: Annual Report of Situation on Environmental Pollution in 1984 (Summary), Kankyo, 10 (4), 1985.

5 ) Hori, Y., Miyoshi, T. and Imaki, M. : Evaluation of Complaints about Public Nuisances as Regional Environmental Indices, Jpn. J. Hyg. 41(5), 1986.

6 ) Saito, K., : Kenko to Kankyo, Asakura-Syoten, Tokyo,
1984, 61-108.

7) Fukushima, M.: Environmental pollution by cadmium and its health effects; An epidemiological approach to the "Itai-itai" disease, In "New Methods in Environmental Chemistry and Toxicology" (Editor: F. Coulston, F. Korte and M. Goto), 231-252, International Academic Printing Co, Tokyo, 1973.

8 ) Kobayashi, E. : AN EPIDEMIOLOGICAL STUDY ON THE HEALTH EFFECTS OF ENVIRONMENTAL CADMIUM, Jpn. J. Public. Health., 29, 123-133, 1982.

9 ) WHO Task Groupe: Environmental Health Criteria 1. Mercury, WHO, 1976.

10) Wakatsuki, T. : Kankyo-Osen to Kenko-Syogai, Kodansha, Tokyo, 1975.

11) M. B. Abou-Donia et al. : Neurotoxic Effect of Leptophos, Experientia, 30(1), 63-64, 1974.

12) Shibutani, M. et al. : Kankyo-Osen to Nogyo, Hakuyusya, Tokyo, 1984.

13) Soda, T., Wakatsuki, T. and Yanagisawa, F. : RURAL HEALTH IN JAPAN, IGAKU SHOIN Ltd., Tokyo, 1969, 89-90.

14) District Administrative Inspection Bureau, Management and Coordination Agency: Result of Local Inspection Concerning Environmental Protection of Livestock Husbandry (Abstract), Industrial Pollution Control, 22 (8), 45 $-52,1985$.

15) Wakatsuki, T. : Noson Igaku, Keisosyobo, Tokyo, 1983, $32-52$.

16) Abe, S. and Takakuwa, E.: The Textbook of Hygiene and Public Health, NANZANDO COMPANY, LIMITED, Tokyo, 1974, 367-405.

17) Sumita, S.: Toshi-Keikaku to Kankyo-Seisaku, JURIST ZOKAN SOGOTOKUSYUU(15), 257-261, July 1979.

18) Environmental Disputes Coordination Commission: The Trend of Environmental Problems from Pollution Complaints, Journal of Environmental Pollution Control, 21 (1), 93-98, 1985.

19) Fukutake, T. : Nippon no Noson (2nd Ed.), Tokyo Daigaku Syuppankai, Tokyo, 1985. 


\section{公害苦情からみた農村における地域環境衛生について}

\section{堀 義治*, 三好 保*, 今木雅英*, 吉村 武*}

地方都市である徳島市域23行政区を対象とし, 農家人口, 農家戸数などの農業関連指標により農 村地域, 非農村地域および混在地域に分類した。そして, 地域環境指標としての公害苦情からみた, これら地域における環境衛生状態の差異について実証的に検討した結果, 次のような知見を得たの で報告する。

1. 農村地域では水質, 悪臭苦情が多く, 混在地域では悪臭, 騒音苦情が多い。また, 非農村地域 では騒音苦情が多いことが認められた。これらは, それぞれの地域における環境衛生要因との関連 性がみられ，このことから，発生しやすい公害事象が地域形態により異なることが認められた。

2. 各地域における公害苦情発生について, 調查前期（1977～1980年）と調查後期（1981～1984年） の経時的変化を検討したところ, 農村以外の地域は総体的に減少の傾向にある。しかし, 農村地域 においては, 粉塺を除くすべての公害事象が増加していることが認められた。このことから, 農村 地域に拈ける環境衛生状態は悪化していることが示唆された。

\section{(1)地域環境衛生 (2)公害苦情 (3)農村地域 (4)公害 (5)悪臭}

\footnotetext{
* 徳島大学医学部公衆衛生学教室
} 